workers requesting a sample of the cells sign a waiver promising not to use the cells, or the antibodies produced from them, for commercial advantage. The university itself is currently negotiating with a number of pharmaceutical and medical instrument manufacturers on terms for supplying them with specific hybridomas and antibodies developed in the university laboratories. Dr Neil Reimers, head of the university's technology licensing office, sees that as providing the university with a steady stream of income under an arrangement agreed with the National Institutes of Health, which provided much of the funding for the original research.

Whether or not Dr Milstein's original work in Cambridge could have been patented is still hotly disputed. Some claim that, as the application of standard cell fusion techniques is in wide use around the world, there is nothing inherently patentable about $\mathrm{Dr}$ Milstein's use of the hybridoma (although novel hybrid cell lines result- ing from the techniques can, it is generally agreed, be patented).

Others, however, feel that as a sufficiently novel application of the techniques, a patent might indeed have been granted, requiring royalties to be paid to anyone using the techniques for commercial purposes.

But the net result is that, like penicillin and other similar stories, monoclonal antibodies may join the list of the ones that got away from the UK.

\title{
Italy's nuclear supremo goes for alternatives
}

The new chairman of Italy's nuclear energy committee plans to spend as much on alternative sources as nuclear power, writes Robert Walgate

For the first time in its history, the Italian National Committee for Nuclear Energy, CNEN, has received money to spend on the research development and promotion of alternative (non-nuclear) sources of energy. On 28 May, the outgoing coalition voted 5 billion lire (about $£ 3$ million) to CNEN to spend mainly on solar and wind power and on energy conservation.

The initiative is the work of CNEN's new Chairman, appointed on 1 February, Dr Umberto Colombo, previously research director of the firm Montedison. Colombo joined CNEN on condition that alternative sources would be included, and the 5 billion lire, he told Nature last week, is only the beginning.

"In Italy there has been no focal point for an energy policy" said Dr Colombo. "We want to become the focal point for all sources of energy which are alternatives to hydrocarbons."

At present, three ministers have partial responsibility for energy policy in Italy: the Minister for Industry supervises CNEN and the Ente Nazionale per l'Energia Elettrica (ENEL), which has responsibility for electricity supply; the Minister of Culture and Scientific Research directs the central body organising basic research in Italy, the Consiglio Nazionale delle Ricerche (CNR); and the Minister of State Participations has responsibility for the Ente Nazionale Idrocarbi (ENI) and the Istituto per la Ricostruzione Industriale (IRI); all of these being bodies with a more or less great interest in energy policy. The Minister for Industry has the largest responsibility -establishing the national energy

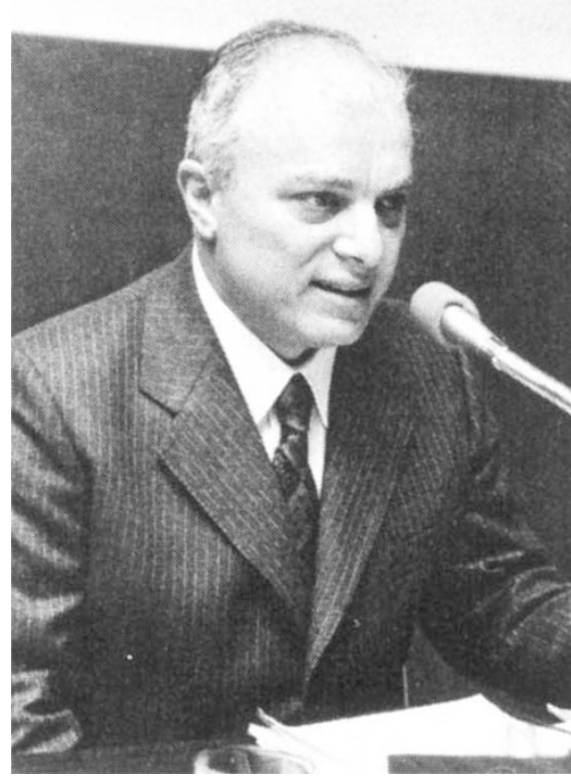

Colombo: "We might even be able to do without fast breeders"

plan, versions of which were published in 1975 and 1977.

"I want to make CNEN the entity responsible for all alternative sources, so that ENI remains responsible for fossil fuels, ENEL for electricity, and CNEN for R \& D and promotion of nuclear and non-nuclear alternative sources, including the most important alternative-energy conservation."

The CNR is also undertaking an energy research project, but Colombo does not foresee conflict, rather coordination: "CNR is more involved universities; our contact is more with with fundamental research and industry". ENEL and ENI have large geothermal projects "so we won't be able to do so much on that-probably we'll concentrate on hot rocks".

Dr Colombo hopes to make a substantial investment in non-nuclear alternative sources. The CNEN budget for 1979 is 200 billion lire (about $£ 115$ million), of which there is only 5 billion lire for alternatives; "but since we have only just started we could hardly be expected to spend much this year". Next year, Colombo hopes to spend 30 billion lire ( $£ 17$ million) on alternatives, and ultimately to reach an expenditure "very close to what we shall be spending on nuclear power".

Would it be possible to spend that much on new sources? "Well if you take some pioneer projects, and you consider that we are not interested so much in basic research as in demonstration units-in conservation, solar, wind, and so forth-it's possible". Clarifying the point, Dr Colombo said he has in mind an ultimate allocation of resources similar to that of the Department of Energy in the US, where nuclear-including fusionstill has more than other sources, but alternative sources have a substantial portion of the budget.

Nevertheless Colombo is convinced that nuclear power must make an increasing contribution to Italy's energy supply; at present one major and three minor reactors supply $0.7 \%$ of Italy's total energy needs and $2.7 \%$ of its electricity. By the year 2000, Colombo would like to see $20 \%$ of Italy's energy needs supplied by nuclear reactors requiring a building rate of two reactors per year; solar power, the main alternative contributor, might supply $7 \%$ by that date, he estimates.

"We do not have North Sea oil, we do not have the gigantic coal fields you have in the UK; at present we are very dependent on imported hydrocarbons. $85 \%$ of our energy is supplied by hydrocarbons, and $76 \%$ is imported energy. This dependence is not acceptable; we are very vulnerable. Our oil bill may go up this year, because of the price increases, by $£ 1$ billion; that's equivalent to exporting another million automobiles, if we want to keep our balance of payments in order . . . so a nuclear programme, as well as a vigorous programme on alternatives, is necessary for Italy."

Colombo makes a fairly classical connection between energy consump- 
tion and economic growth. After conservation measures have been applied, he estimates Italy will be consuming $40 \%$ more energy in the year 2000 than now. "Don't measure that against UK standards. Our per capita consumption is 2.4 tonnes of oil equivalent; you have 3.7 ; so we must make great progress to reach other European countries. We can't possibly stay much behind them if we want to develop our own industry." The $40 \%$ increase corresponds to an annual rate of about $1.4 \%$, and is based on an assumption of economic growth of $2.5 \%$ per year with an 'energy elasticity' (ratio between energy and economic growth rates) of some $50 \%$.

Colombo is in the process of constructing his first 5-year plan for CNEN. "In the past everyone has been very superficial: both parliament and government, and CNEN, ENEL and the industry." Now Colombo believes that "we at CNEN must express our opinions forcefully, justify them with numbers and facts, and submit our ideas to a discussion in parliament." Then it is a matter of responding to the political will of parliament and government. Colombo hopes to submit his plan by the end of the summer.

Previously CNEN's energy policy was "very much in the air, something rather abstract". CNEN was moving in many different directions, in each of them "below the necessary threshold" of potential, manpower, and capital. Furthermore CNEN has been hampered by the government's inability to define a politically and publically acceptable nuclear plan. But in any case the previous plan "was too ambitious, and not credible at all".

"There were gigantic plans to build up a huge number of power stations, but the plans were never implemented.

They required almost a menu of different nuclear technologies, which -particularly after the Harrisburg incident-is no longer advisable. We need to concentrate on one type of proven reactor, and to put a great emphasis on the safety and security aspects of that one. I therefore will use my influence and my power-as far as possible-to determine this concentration of effort on one type of reactor. I do not think we have the technical or organisational capability to go ahead in many different directions in nuclear power in Italy."

The reactor will probably be the Westinghouse pressurised water reactor, which has also been chosen in France and Germany; this not because Colombo has any particular attachment to that but because the concentration of international effort and experience on it should make it one of the safest systems.

Nevertheless the Italian industry will continue to work on other reactor systems, like the Tirrhena heavy water reactor presently under construction "to enable the industry to work on the commercialisation of CANDUtype reactors throughout the world". CNEN will also do direct and sponsored research and development of fast breeders and fusion reactors.

On nuclear safety, CNEN is at present both promoter and regulator of nuclear power-an unsatisfactory situation which Colombo expects to be changed sometime next year. At present "they both depend on me" says Colombo. But for the moment he is reluctant to give up the dual role. "We must first make the safety division of CNEN stronger technologically; I want to fortify it a little bit before giving it to somebody else. Secondly, the safety problem in nuclear plants is not just a health problem, it's a matter of checking the design, construction, and operation of very complex technological plants, which requires some technical expertise. If safety is left in the hands of medical people alone, and epidemiologists, they will cover very well the biological part but won't be competent in the other. So we need both, and we need to move towards the creation of an independent organisation. I hope it will be constituted under the premier, who controls both industry and health, allowing the organisation to include both types of competence".

"I am grateful to those who have been against nuclear power, although I do not share their ideas" said Colombo. "They have brought the problem to the surface, and obliged us to be more frank and serious in our considerations." In the past, he said, the nuclear authorities in Italy have been too arrogant in their dealings with the public; it is time to consider clearly and openly all the risks, both with and without nuclear power.

Furthermore, "if we are able to develop alternative sources immediately so that they can penetrate by $7 \%$ by the year 2000 , and take off thereafter, we might even be able to do without fast breeders. But if the rate of penetration is slow, and if nuclear fission is the bridging energy source up to 2020-2030, we will have serious problems with uranium."

Colombo therefore wants to keep fast breeders open as an option, and Italy is already building pilot reprocessing plants "so that when we have to decide, we can decide from a strong position".

Ultimately, however, it is all up to the Italian government. "I'm powerful as far as propositions are concerned" says Colombo "but I'm not the one who decides". Colombo will be submitting his first 5-year plan to the government "in a month or two".

\section{Energy efforts should shift from research to conservation}

THE US Administration is placing too much emphasis on research into new energy technologies, and not enough into conservation techniques even though the latter have already produced considerable energy savings, according to a paper published by the Union of Concerned Scientists.

Dr Vince Taylor, the author of the paper, points out that improvements in efficiency made by industry since 1973 have contributed twice as much as oil obtained through the Alaska pipeline to the energy needs of the US last year. " $90 \%$ or more of the solution to our energy problems will come from improvement in energy productivity$10 \%$ or less from supply extension. Yet the administrative and budgetary resources are being allocated in just the opposite proportions," Dr Taylor writes.

Dr Taylor lays out what he calls an 'easy path' strategy which, he claims, would redress imbalances in the energy budget by concentrating on factors such as improving the efficiency of motor vehicles and of energy use in domestic and commercial buildings, and selective switching between fuels. This strategy, he says, does not depend for its success on expensive and uncertain long-range $R \& D$ projects.

\section{Carter proposes new fund to clear up chemical wastes}

President Carter has submitted to Congress legislation setting up a \$1.6 billion fund for cleaning up hazardous chemical waste dumps and the effects of chemical and oil spills, in what one aide has referred to as "the most important environmental legislation" to be proposed by the Administration in the current year.

The President's move has been prompted both by general concerns about the effects of industrial pollution, and more specifically by a number of recent highly-publicised cases in which the previous dumping of toxic wastes has led to serious environmental and health hazards.

Against the advice of a number of federal agencies (although not the Environmental Protection Agency) the President has also decided that the industries responsible for the wastes should carry a large part of the bill for clearing them up. Consequently $80 \%$ of the fund would come through a series of fees imposed on oil refiners and chemical manufacturers. 